\title{
Leishmanial Infection: Analysis of its First Steps. A Review
}

\author{
MC de Almeida/+ , V Vilhena* , A Barral*/**, M Barral-Netto*/** \\ Departamento de Patologia e Núcleo de Medicina Tropical, Faculdade de Medicina, Universidade de Brasília, Campus \\ Universitário Darcy Ribeiro, Asa Norte, 70910-900, Brasília, DF, Brasil *Centro de Pesquisas Gonçalo Moniz-Fiocruz, Salvador, \\ BA, Brasil ** Faculdade de Medicina, Universidade Federal da Bahia, Salvador BA, Brasil \\ The first steps in leishmaniasis are critical in determining the evolution of the disease. Major advances have \\ recently been done in understanding this crucial moment. Fundamental research in parasite-vector interaction, \\ parasite biology, insect saliva, and vertebrate host response have shed new light and uncovered a most fascinating \\ and complex moment in leishmaniasis. We review here some of these aspects and we try to connect them in a logical \\ framework.
}

Key words: Leishmania - Phlebotomus - monocyte - immunity - ignorance

Leishmaniasis is a serious and sometimes fatal disease causing much suffering in human beings. However, from the strict biological point of view, man can be seen as just one of the actors of the drama. The others are the parasite, the insect, and the double: the mouse.

In the initial scenario of human leishmaniasis there are then three central players: the parasite, the insect, and the human being. The biological conversation among these players evolves dynamically. The initial steps are fundamental in determining the fate of drama or disease. In most of these crucial moments, due to ethical imperatives, the mouse double comes in scene. Thus, the initial steps of Leishmania infection in humans are really largely unknown. We try to infer from the subtleties of the conversation what will happen in the next act.

We must, however, be sure that chance and actors' hidden strategies could radically change our deterministic thought. Finally, the double could not act exactly as the man.

\section{THE PARASITE AND THE INSECT}

The genus Leishmania, a group of protozoan flagellates of the family Trypanosomatidae, order Kinetoplastida, has two morphological forms in its lifecycle - the amastigotes and the promastigotes. The amastigotes live inside lisossomal vacuoles present in phagocytic cells of the vertebrate host, namely monocytes and macrophages, which are ingested by the female phlebotomine sand fly when it takes an infecting bloodmeal (Lainson et al. 1987, Chang et al. 1990, Alexander et al. 1999). Once in the insect midgut the parasite transforms into the promastigote, the extracelular form, which may be found free or attached to the intestinal cuticle or microvilli (Walters et al. 1989a, b, Killick-Kendrick 1990a).

\footnotetext{
Financial support: NIH-NI AID, CNPq

${ }^{+}$Corresponding author. Fax: +55-61-273.3907. E-mail: marcalmo@unb.br

Received 14 July 2003

Accepted 2 October 2003
}

Diptera of the subfamily Phlebotominae are the only vectors of the various Leishmania species, with the genus Phlebotomus hosting the Old World species and Lutzomyia the species of the New World (Shaw \& Lainson 1987, Killick-Kendrick 1990b). In these blood-sucking insects the parasite develops a complex series of morphological (Adler \& Theodor 1931, Walters et al. 1989a, b, Killick-Kendrick 1990a) and functional (Sacks 1989) modifications. Shortly, the parasite differentiates from a dividing procyclic promastigote stage that avoids expulsion from the midgut by attaching to the gut wall, to a nondividing metacyclic promastigote stage that is unable to attach to the midgut and migrates to the mouth parts (Adler \& Theodor 1931, Killick-Kendric 1987, Walters et al. 1989a, b, Killick-Kendrick 1990a, Pimenta et al. 1992, Mahoney et al. 1999). Sacks and Perkins (1985) reported, for example, that clones of $L$. (L.) amazonensis in $L u$. longipalpis were not able to infect BALB/c mice when inoculation was carried out 3 days after the insect's infection, but the inoculum became progressively infective from the 4th until the 7 th day of development in the sand fly midgut. Coincidentally, the maximum infective capacity occurs at the time of a new bloodmeal. When the infected phlebotomine probes a new host, it regurgitates about 1 to 1000 metacyclics, closing the life cycle (Adler \& Theodor 1935, Warburg \& Schlein 1986). It seems clear that this coordination of events takes the parasite to an optimum opportunity to infect the vertebrate host and perpetuate its cycle.

\section{THE HOST RESPONSE}

When the haematophagous insect bites a vertebrate host (Figs 1,2) it introduces its mouthparts into the skin, lacerates blood vessels causing hemorrhages and then feeds in the haemorrhagic pool formed (Ribeiro 1987). In the generation of leishmaniasis primeval blood lake not only the mechanical action of insect probocis but also enzymatic action of insect saliva, hyaluronidase (Charlab et al. 1999) for example, could be acting. This is a complex interaction. It was described that the site of inoculation (dermal or subcutaneous) influences the development of the lesion (Poulter \& Pandolph 1982, Nicolas et al. 2000). In this particular situation, the short length of the 


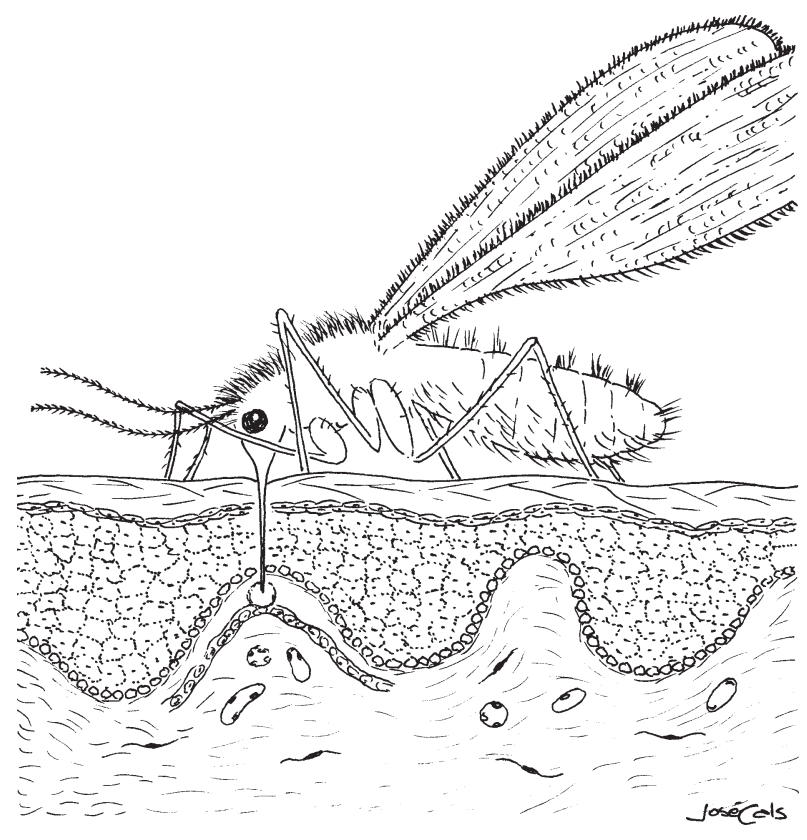

Fig. 1: illustration of a phlebotominie bitting in a superficial dermal vessel.

phlebotomine proboscis determines that only the superficial vessels of the dermis, at the dermal-epidermal interface, can be reached. Without the vasodilator activity of its saliva, the sand fly would hardly achieve the dermal capillaries (Ribeiro et al. 1984). At this point, a battle takes place between the host resistance and the insect's strategies to obtain blood. At the host's side, the natural defense mechanisms will be activated due to the presence, at the site of inoculation, of agents like complement system, thrombin, kinins, platelets, natural antibodies, phagocytes, etc. By the vector's side, the pharmacological agents of the saliva are maxadilan, adenosine, interleukin 2 (IL-2) binding factor, apyrase, prostaglandins, etc. (Ribeiro 1987, Gillespie et al. 2000). This scenario, where the players will act for the first time, will determine the course of the hostparasite relationship. It was demonstrated, for example, that in mice inoculated with a mixture of phlebotomine saliva and $L$. (L.) major promastigotes, the lesions grew faster and were bigger than those of mice inoculated only with promastigotes (Belkaid et al. 1998). The host capacity of immediate response to this aggression through the kinins (vasoconstriction), coagulation (thrombosis), and phagocytic-neutrophilic systems, could decrease the vectorial competence, hampering or even preventing the insect ability to blood-feed (Gillespie et al. 2000). However, the sand fly saliva has potent vasodilatatory agents, maxadilan (Lutzomyia) (Lerner et al. 1991) and adenosyne (Phlebotomus) (Ribeiro et al. 1999), antiplatetelet aggregation, apyrase (Lutzomyia and Phlebotomus) (Valenzuela et al. 2001), and prostaglandin E2 (vasodilatatory and immunossupressive actions) (Reiner et al. 1987, Lonardoni et al. 2000) production stimulators (Soares et al. 1998), that counterbalance this response. In general, the vectorial strategy of inhibiting host coagulation system, as host procoagulant and inflammatory response are closely linked (Bernard et al. 2001), reduces the host sensitization and inflammation, both of major importance for parasite transmission (Gillespie et al. 2000). It has been shown, for example, that the previous sensitization of mice with $P$. papatasii sonicated salivary glands is capable of eliminating the enhancing effects of saliva on $L$. (L.) major infection, notably the precocious epidermal generation of IL-4 and IL-5 (Belkaid et al. 1998). However, in an apparent case of conflict of interests, $P$. papatasii, due to increased blood flow in inflamatory area, benefits from induced host delayed type hypersensivity response (Belkaid et al. 2000). Strong correlation has been also found between delayed type hypersensivity response to Leishmania antigens and anti-salivary gland IgG1 and IgE levels from children living in endemic areas of visceral leishmaniasis (Barral et al. 2000, Gomes et al. 2002). Thus, previous non-infected phlebotomine bites may confer a degree of protection against infection (Kamhawi 2000). Effective vaccination approaches able to protecting the host against Leishmania infection, using maxadilan (Morris et al. 2001) or other protective proteins in the insect saliva (Valenzuela et al. 2001), have been reported in mice.

In a subsequent moment, the establishment of a Thelper (TH) 1 response which protects against intracellular pathogens, or a $\mathrm{TH} 2$ host response that is linked to allergy or protection against extracellular pathogens, will be essential for the control (resistance) or, on the other side, the more or less intense development of the infection (Reiner \& Locksley 1995).

Basically, three hypothesis have been proposed for explaining the $\mathrm{TH} 1 / \mathrm{TH} 2$ imbalance in experimental leishmaniasis (Reiner \& Locksley 1995): (1) different peptides stimulate distinct groups of TH1 or TH2 clones, (2) a particular pattern of cytokines and cofactors, produced by innate immune system accessory cells, would be the reason for the divergence, (3) under stimulation, $\mathrm{T}$ cells of different mice strains would have an innate tendency for the development of one of the two poles of the response (clones of T cells derived from C57BL/6 mice for example, would take the TH1 direction while cells from $\mathrm{BALB} / \mathrm{c}$ would go for the TH2 pole). Reinforcing the first hypothesis, a LACK (Leishmania homologue of mammalian receptors for activated $\mathrm{C}$ kinase 1) peptide was identified in L. major which, recognized by BALB/c V $\beta 4$ V $\alpha 8$ CD4+ cells, induces IL-4 secretion by these cells 12 to $14 \mathrm{~h}$ after infection, driving the immune response to the TH2 side (Launois et al. 1997, 1999). However, this response can be changed to the TH1 side with low antigen dose (Menon \& Bretscher 1998), early presence of IL-12 or IFN- $\gamma$ (Scott 1991, Scharton-Kersten \& Scott 1995, Doherty \& Coffman 1996) or IL-4 injection in the first $12 \mathrm{~h}$ of infection (Himmelrich et al. 2000, Biedermann et al. 2001). Notwithstanding, it is controversial whether the cytokines that induce $\mathrm{TH} 1$ or $\mathrm{TH} 2$ differentiation instruct the development of naïve $\mathrm{T}$ helper cells or select from previous committed TH1 or TH 2 cells (Coffman \& Reiner 1999). It was thought that a divergent production of IL-12 by dendritic cells of BALB/c and C57BL/6 mice could explain the $\mathrm{TH} 1$ and $\mathrm{TH} 2$ response in these mice (von Stebut et al. 1998). Afterwards it was found that dendritic cells of both lineages were able to produce IL-12 in 
response to L. major infection (von Stebut et al. 2000).

So far it has been given more emphasis in searching peptides that, recognized by the adaptative immune system, will direct the immune response to the TH1 or TH2 side. Recently, however, it has been shown that a recombinant leishmanial protein, a homologue of eukaryotic ribosomal elongation and initiation factor $4 \mathrm{a}$ (LeIF), induces the production of IL-12 and IL-18 by APC cells (Skeiky et al. 1998, Borges et al. 2001). LeIF also directs the adaptative immune response to the TH1 side in BALB/c mice (Skeiky et al. 1998). Moreover, contrary to previously held beliefs, due to IL-12 action, LeIF converts TH2 cell populations from $L$. (L.) major infected BALB/c mice to IFN- $\gamma$ producers (Skeiky et al. 1998). These findings expand the classical group of the so called pathogenassociated molecular patterns (PAMP), mainly applicable to homopolymers that are integral components of bacterial and fungal cell walls (Borges et al. 2001). The classical PAMP group includes: LPS, peptidoglycan, lipoteichoic acid, mannans, bacterial DNA, double strand RNA, and glucans (Medzhitov \& Janeway 2000). The PAMP are recognized in the host by pattern-recognition receptors (PRR). These receptors are chiefly present in APC cells as, for example, monocytes, macrophages, B cells, dendritic cells (Medzhitov \& Janeway 2000) and neutrophils (Hayashi et al. 2003). Toll-like receptors allow immediate effector cell response upon PAMP recognition. Leishmania, with its characteristic down modulating effects on monocytes/macrophages (see below), seems to avoid or overcome this immediate response. Accordingly, L. (L.) major was shown to induce the transcription of IL- $1 \alpha$ through an adapter protein, MyD88 (myeloid differentiation factor 88), known to interact with Toll-like receptors (Hawn et al. 2002). Hence, signaling pathways of Toll-like receptors are involved in the inflammatory response to Leishmania infection. On the other hand, Leishmania had inhibitory effects acting on RNA transcription and translation, as RNA levels in infected macrophages were lower than controls, and no protein was detected in supernatants (Hawn et al. 2002). Leishmania does not have a true cellular wall, but it has an analogous structure, its LPG coat, fully developed in metacyclic forms (Pimenta et al. 1991). LPG molecules from both procyclics and metacyclics were found to directly activate NK cells through Toll-like receptor-2 (Becker et al. 2003). Interestingly, L. major metacyclic LPG had a more intense stimulatory effect than procyclic LPG. Both IFN- $\gamma$ and TNF- $\alpha$ were detected in culture supernatants of stimulated cells (Becker et al. 2003). Therefore, IFN- $\gamma$ production by NK cells could be via IL-12 and IL-18, derived from PAMP stimulated APC cells (Borges et al. 2001), or directly by PAMP binding to its own PRR in NK cells (Becker et al. 2003). The recent report of NK1 and NK2 subsets reminiscent of TH1 and TH2 cells (Peritt et al. 1998), and the findings of Borges et al. (2001) and Becker et al. (2003), address an important role for NK cells at the initial phases of Leishmania infection - that of immunomodulatory cells.

It seems thus clear that the pattern of innate immunity at the initial phases of infection is of major importance for the definition of a TH1 or TH2 response (Scott 1991,
Scharton-Kersten \& Scott 1995, Doherty \& Coffman 1996, Menon \& Bretscher 1998). At this initial point, characterization of the infected antigen presenting cell is one of the fundamental aspects, since the interaction of this cell with the lymphocyte will be the basis for the development of the acquired immune response.

In the haemorrhagic pool formed at the site of insect bites (Fig. 2), parasite growth is mainly allowed by a phagocytic cell - the monocyte, although it is not the most abundant phagocyte. Neutrophils are short lived cells present in higher numbers, but likely to play a major role in parasite elimination instead of its hosting (Chang 1981). However, neutrophils may play other roles, such as secreting cytokines like IL-12 and TGF- $\beta$ (Tacchini-Cottier et al. 2000) and may also present antigens via class II MHC in the presence of GM-CSF (Gosselin et al. 1993). It is possible that apoptotic infected neutrophils may yet constitute an important initial source of Leishmania antigen for dendritic cells (de Almeida 2002). Macrophages are not present at the hemorrhagic pool and are scarce in the normal, non-inflamed surrounding skin (Urmacher 1997). Mature epidermal dendritic cells may not be able to ingest promastigotes (von Stebut et al. 1998, 2000), or do it in a limited fashion (Konecny et al. 1999, Marovich et al. 2000), even when parasites are readily accessible, as in case of excessive inocula (Lira et al. 2000). However, these cells phagocytose and harbour amastigotes (von Stebut et al. 1998). These findings may be explained by a sequential model of infection with initial parasitism of monocytes/macrophages and then of dendritic cells.

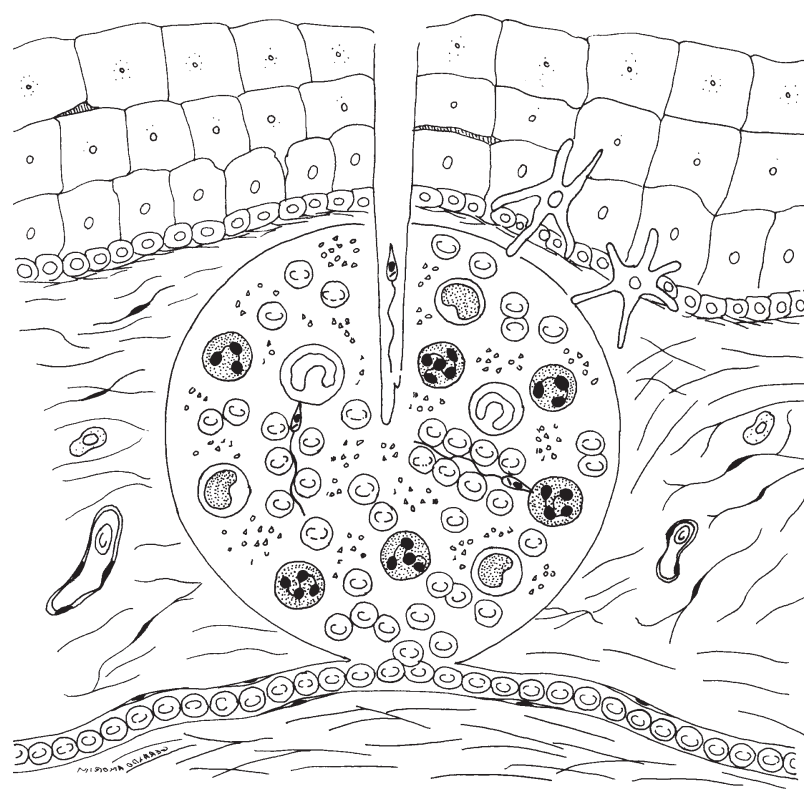

Fig. 2: illustration of phlebotomine feeding and promastigote regurgitation in the dermal blood lake. The immunoadherence of erythrocytes to promastigotes is shown with initial transference, at left of the insect proboscide, of a promastigote to a monocyte and, at the right to a neutrophil. At the dermo-epidermial interface, two Langerhans cells are bordering the blood lake at right of the insect proboscide. The drawing is not exactly in scale. The cellular elements are not in proportion, for example, neutrophils are ten times more abundant than monocytes in human blood. 
Peripheral tissue immature dendritic cells could be from epidermal origin (Langerhans cells), monocyte derived or from other blood precursors (Mellman et al. 1998). These cells are more endocytic than the mature dendritic cells (Mellman et al. 1998). Consequently, these cells could uptake apoptotic infected neutrophils, leishmania debris, including genetic material, and in low numbers (2-3), the parasite itself (Blank et al. 1993, Henri et al. 2002). Most importantly, immature dendritic cells are exposed, at peripheral sites, to a maturation stimulus that instruct them to skin exodus (Mazzoni et al. 2001). At lymph node sites, these cells will become highly competent APC cells. Leishmania promastigotes, dead or alive, were shown to inhibit dendritic cell motility (Jebbari et al. 2002). Additionally, it has been found that chemokine receptor 2 (CCR2) deficiency is associated with impaired Langerhans cell migration to the lymph node and deficiency, in the lymph node, of TH1 priming CD $8 \alpha^{-}$dendritic cells (Sato et al. 2000). More than that, CCR2 gene knockout in $L$. major resistant mice led to $L$. major susceptibility (Sato et al. 2000). Could Leishmania, changing host cell patterns of chemokine synthesis or chemokine receptors, intercept the danger message in the way to the sentinel lymph node? But, even if the migration occurs, the previous peripheral micro-environment appears to determine, at the lymph node, the future TH1/TH2 driving capacity of the mature dendritic cells (Mazzoni et al. 2001). It has been shown, for example, that histamine alters the polarizing capacity of immature human monocyte derived dendritic cells, but not its priming capacity, mainly due to the downregulation of its IL-12 and IL-18 production (Mazzoni et al. 2001). Prostaglandin E2, that can be elicited in the host by components of insect saliva (Soares et al. 1998), was also described to induce IL-12 deficient TH2 priming dendritic cells (Kalinski et al. 1997). Besides these known host cell elements and peripheral micro-environment substances, other apparently secondary actors must be considered. Mast cells, basophils and eosinophils could be present at the initial phase of leishmania infection, in the tissue or in the blood lake. Mast cells and basophils are both able to produce histamine and cytokines, like IL-4, IL-10 and IL13 (Falcone et al. 2000, Mazzoni et al. 2001), which could act on immature dendritic cells. Eosinophils have also been described as cytokine producing APC cells (Weller \& Lim 1997, Shi et al. 2000). Platelets, abundantly present in the blood lake, could be another player. Dominguez and Torano (2001) showed in vitro adherence between platelets and promastigotes in mammals other than primates. From these data, it is unlikely that platelets could have a direct action on promastigotes in the human infection, and its role in non-primate mammals is unknown. However, platelets were described to interact directly with monocytes, inducing monocyte secretion of monocyte chemotactic protein-1 and IL-8 (Weyrich et al. 1996). Thrombin stimulated platelets cause superoxide anion generation by neutrophils and monocytes (Nagata et al. 1993). Platelets and mast cells have also been suggested to be a source of CD40-Ligand involved in dendritic cell maturation (Lane $\&$ Brocker 1999). Possible sources of platelet activation at the initial phases of leishmania infection would be collagen exposition by insect byte, thrombin generation due to endothelial lesion, or endothelial/monocyte platelet activating factor (Lonardoni et al. 2000). In vivo, the potentially powerful platelet action is probably prevented by insect saliva agents (see above). Nevertheless, it remains a plausible hypothesis that platelets could have a role as a host protecting agent in leishmaniasis.

Leishmaniasis occurs chiefly in tropical and subtropical areas of the globe, where there is intense sun skin exposition. Ultraviolet (UV) irradiation has intense effects on skin immunology including: reduction in the density and antigen presenting ability of Langerhans cells in the epidermis (el-Ghorr \& Norval 1997), increased Keratinocyte secretion of IL-10 and prostaglandin E2, with increased serum levels of IL-4 (Shreedhar et al. 1998), induction of suppressive IL-12p40 homodimers by dendritic cells and macrophages (Schmitt \& Ullrich 2000). Thus, UV irradiation seems to induce a resultant immunosuppressive effect with decreased Th1 cell activation and enhanced Th2 cell activation (Shreedhar et al. 1998). This kind of microenvironment would be an ideal one for Leishmania infection. Unexpectedly, it was found that low dose UV irradiation, increasing serum and skin levels of IFN- $\gamma$ and TNF- $\alpha$, conferred protection in murine cutaneous leishmaniasis (Giannini 1986, Khaskhely et al. 2001, 2002). Whichever the way, we have here a immunomodulatory agent that could be of broad epidemiological importance.

PARASITE'S GENERAL STRATEGY AT THE INITIAL PHASES OF LEISHMANIA INFECTION

It is a maxim in microbiology that the higher the infective inoculum the more the chance of the agent to establish the infection. Paradoxically the natural infection by Leishmania spp. does not use this law - the phlebotomine regurgitates circa 100 (in a range of 1-1000) metacyclics (Warburg \& Schlein 1986). In spite of that, several factors allow the parasite to infect host cells. First, metacyclics are more resistant to complement lysis than log phase promastigotes (Franke et al. 1985, Sacks \& Perkins 1985, Sacks 1989, Dominguez et al. 2002). Additionally, it has been suggested that, metacyclics interaction with serum complement could be different from procyclic promastigotes (Puentes et al. 1988). Procyclic cells would activate the alternative pathway whereas metacyclics activate the classical pathway, even in the absence of immune serum (Puentes et al. 1988). More recently, however, other authors have confirmed previous data (Mosser et al. 1986) that both complement pathways are activated (Dominguez et al. 2002). Surprisingly, the C3 molecule binds in its active, lytic form, C3b, on the surface metacyclic lipophosphoglican (LPG). The metacyclic complement resistance is partly due to metacyclic LPG as it has an increase in subunit numbers and a modification in its sugar components which gives structurally a thicker appearance to the parasite surface and hampers the C5-9 complex lytic pore formation (Puentes et al. 1990, Pimenta et al. 1991, McConville et al. 1992). In addition, conversion of $\mathrm{C} 3 \mathrm{~b}$ to $\mathrm{C} 3 \mathrm{bi}$ could be happening through gp63 (Brittingham et al. 1995, Dominguez \& Torano 1999) which is much more expressed in metacyclic than procyclic surface (Kweider et al. 1989, Ramamoorthy et al. 1992). In 
the absence of $\mathrm{C} 3 \mathrm{~b}$ mediated lysis the $\mathrm{C} 3 \mathrm{~b}$ coated metacyclic will be more easily phagocytosed. The complement resistance of metacyclics has been shown indeed not to be absolute but a time dependent process (Dominguez et al. 2002). IgM mediated immunoadherence mechanisms (Mosser et al. 1986, Dominguez et al. 2002), due to its very fast kinetics, permit the phagocitosis before the complement lyses all parasites (Dominguez \& Torano 1999, Dominguez et al. 2002). Thus, even in low number, the parasite is able to establish the infection. Once inoculated, due to the initial conditions, it is predicted that the parasite density will be very low, 0.03-0.1 parasite per phagocyte (de Almeida 2002). This very low density, instead of being a disadvantage, could lead to ignorance, a previous unreported escape mechanism in leishmaniasis (de Almeida 2002, de Almeida et al. 2003). Ignorance is defined by the presence of functional $\mathrm{T}$ cells that are not reactive to a given antigen (Abbas et al. 2000). However when properly stimulated these cells could react and proliferate in response to this antigen. On the other hand, in anergy $T$ cells become irreversibly unresponsive to the antigen. Ignorance may be due to several factors: low antigen concentration (Voehringer et al. 2000), inappropriate antigen presentation by non professional antigen presenting cells (APC), low number of reactive cells, non activation of the APC (Shevach 1999), and immunoprivileged sites (Kurts et al. 1999). Except for the last condition, all these factors can be present at the initial phases of Leishmania infection. It has also been recently suggested that most molecules involved in host invasion have been evolutionary selected for low immunogenicity by long exposure to the host immune system, or are down modulated after parasite invasion as seen with LPG and gp63 (Chang et al. 2003).

What would be the advantages and disadvantages of ignorance for Leishmania spp. infection? An obvious disadvantage could be that when infecting in low number the parasite could be destroyed by host innate immune system before establishing the infection. However, as previously commented, a series of ingenious mechanisms due to insect saliva and the parasite itself permit its relative success here. It is also a factor of success a ready access to a permissive host cell, the monocyte (Chang et al. 1986, 2003). On the other hand, once internalyzed the parasite could grow freely inside the permissive cell, eventually changing the host microenvironment in parasite favour. It has been demonstrated (Moore \& Matlashewski 1994), for example, that infection of bone marrow-derived mouse macrophages (BMMs) by L. (L.) donovani promastigotes or treatment of BMMs with LPG, inhibits macrophage apoptosis. Another possible advantage would be the inability to generate immunity by aborted attempts of infection. On the other hand, once immunity is established probably it will hamper reinfection.

What would be the biological constraints that may lead the parasite to infect in such low numbers? There are some evidences that excessive parasite growth could be dangerous for the phlebotomine (Killick-Kendric 1987). Besides that, excessive parasite growth would require abundant nutrients, but its cycle in the insect gut lasts days after the blood meal ingestion (Killick-Kendric 1987).
The sugars ingested by the insect, meanwhile, could sustain differentiation but not parasite growth, as in vitro experiments have shown (Schlein et al. 1987). Probably, there is also a strong volumetric restriction to parasite growth in anterior parts of the sand fly gut (Dominguez et al. 2002). Finally, the insect proboscis, where metacyclics are found prior to infection, is a starving place in the insect gut, and usually it hosts no more than 10 metacyclics (Killick-Kendric 1987).

Due to metacyclic time dependent serum complement resistance, the parasite needs desperately to bind to its host cell. This critical time in Leishmania's life has been estimated to be less than $2.5 \mathrm{~min}$ (Dominguez et al. 2002). From the Leishmania point of view, if we could have it, the complement aggression appears to be excessively draconian. However, it could be viewed as a kind of rite of passage. The complement aggression provides Leishmania with the key molecules (C3b, C3bi) for entrance, through the CR1, CR3 doors (Rosenthal et al. 1996) in the monocyte/macrophage sanctuary. The binding of the parasite binding to CR3 (CD11b) could induce suppression of the synthesis of IL-12, a main TH1 driving cytokine (Reiner et al. 1994, Marth \& Kelsall 1997, Sutterwala et al. 1997). Additionally, complement coated parasites may have increased survival inside macrophage (Mosser \& Edelson 1987, Mosser \& Brittingham 1997). Within the macrophage the parasite has other strategies for evading the host immunological system (Reiner 1994, Reiner et al. 1994, Buates \& Matlashewski 2001). One of these strategies is the down modulation or not induction of molecules involved directly or indirectly in antigen presentation. For example $L$. (L.) donovani infection has been shown to down modulate the expression of MHC I and II molecules in human monocytes (Reiner et al. 1987). We have also shown that $L$. (L.) chagasi infected human monocytes have a diminished HLA-DR expression. A similar decrease is observed in IFN- $\gamma$ stimulated HLA-DR and HLA-ABC expression in infected human macrophages (de Almeida et al. 2003).

Studies in mice are controversial, concerning the ability of Leishmania infection to induce changes in the expression pattern of costimulatory molecules of monocyte/macrophage. No changes on costimulatory molecules expression were found on macrophages from the resistant C57BL/6 mice upon infection with $L$. (L.) donovani (Saha et al. 1995) or with $L$. (L.) major (von Stebut et al. 1998). L. (L.) donovani infection of macrophages from susceptible BALB/c mice marginally increases CD54 (Saha et al. 1995) but fails to trigger CD80 (Kaye et al. 1994). L. (L.) major was also not able to change the low level of CD80 expression and the basal level of CD86 expression in human macrophages (Brodskyn et al. 2001). The pattern of expression of costimulatory molecules has been implicated in driving the immune system to a $\mathrm{TH} 1$ or a $\mathrm{TH} 2$ response leading to secretion of cytokines that could activate the macrophage and arrest the infection or burst it (Kaye 1995, Hunter \& Reiner 2000). A direct relationship between costimulatory molecules, particularly CD80 and CD86, and a TH1 or TH2 response in established leishmaniasis models is not clear (Murphy et al. 1997, Hunter \& Reiner 2000). Blockage of CD86 
reduced parasitism in BALB/c mice (with a predominant $\mathrm{TH} 2$ response), implicating CD86 in production of TH2 cytokines and disease induction (Brown et al. 1996, Tsuyuki et al. 1997). In contrast blocking CD86 in cultures of $L$. (L.) major-infected human macrophages plus peripheral blood lymphocytes lead to a significant inhibition of IFN- $\gamma$ production (Brodskyn et al. 2001), a classical TH1 cytokine. An apparent contrary result was also obtained in $L$. (L.) donovani model of visceral leishmaniasis where CD86 blocking increased IFN- $\gamma$ production and reduced parasite burden (Murphy et al. 1997). A possible explanation for these results is that a more complex picture could be involved in driving lymphocytes to TH1 or TH2 response (Kim et al. 1999). Whereas CD80 or CD86 expression leads to high IL-4 and IL-10 production by naive CD4 T cells, co-expression of CD54 plus CD80 or CD 86 resulted in decreased IL-4 and IL-10 production (Luksch et al. 1999). Additionally, costimulation by $\mathrm{CD} 80$ and CD54, but not by CD 80 or CD54 alone, leads to rapid TNF- $\alpha$ cytotoxicity, tumor rejection and generation of memory T cells (Nishio \& Podack 1996). Moreover, both B7 and CD54 may co-regulate activationdriven maturation of T cells (Damle et al. 1992). We have found (de Almeida et al. 2003) that $L$. (L.) chagasi infection does not induce CD54 expression in human monocytes or macrophages, and a negative correlation was observed between CD54 and CD86 expression. It is possible that avoidance of simultaneous expression of these two molecules and consequently impaired costimulatory activity is a escape mechanism exploited by $L$. (L.) chagasi . Whichever explanation is given, however, it has to be viewed with criticism mainly due to increasing number of costimulatory molecules that have been reported (Sharpe $\&$ Freeman 2002) and the consequently ignored interactions or combinations of effects among these molecules.

Recently it has been shown (Buates \& Matlashewski 2001 ) that $L$. (L.) donovani infection leads to down modulation of aproximately $40 \%$ of a large number of tested genes in mice macrophages, including genes of NFk $\beta$ family, which are involved in inflammation and immunity. Leishmania infection does not induce TNF- $\alpha$ or IL-12 production in human monocytes (Reiner et al. 1990, Ghalib et al. 1995, Sartori et al. 1997) or macrophages but inhibits IL-12 production by LPS-stimulated monocytes. In addition, we have shown (de Almeida et al. 2003) that some striking inhibitory effects, as for CD54 expression or IL-12, were only observed if the infected cells were challenged with an inflammatory stimulus, LPS. Indeed, some reports (von Stebut et al. 1998, Marovich et al. 2000) had not identified changes in the pattern of costimulatory molecules, MHC class II and basal level of cytokine production in infected macrophages. It is surprising that the parasite induces few changes or no changes at all in the resting host cell. These reinforces the possibility of ignorance at most initial steps of Leishmania spp. infection. Ignorance would be broken by improper operation of down regulatory mechanisms, or when the parasite or its antigens reach highly competent dendritic cells (Gorak et al. 1998, von Stebut et al. 1998, Marovich et al. 2000), due to parasite multiplication in the initial permissive host cells.

\section{MAN AND MICE}

Although the murine model is the most frequently employed for the study of Leishmania infections, it presents a series of important differences in relation to the human disease that limit the possibility of extrapolations. Nevertheless, the application of this model is still essential for the study of human leishmaniasis, insofar as ethic imperatives hamper the analysis of many aspects of the human disease, making in vitro and in vivo studies necessary. In mice, for example, leishmaniasis does not reproduce the mucosal and visceral forms observed in humans. The clear involvement of nitric oxide (NO) in intracellular parasite elimination and the clear-cut predominance of $\mathrm{TH} 1$ and $\mathrm{TH} 2$ responses related to resistance or susceptibility observed in mice are not seen in humans (Stenger et al. 1996). In spite of the mentioned limitations of the mice model, recent observations using inocula similar to those of the natural infection achieved success in generating asymptomatic, and subclinical states with a pattern of $\mathrm{T}$ helper response similar to that found in man (Belkaid et al. 2001, Uzonna et al. 2001). Surprisingly, higher inocula $\left(\sim 10^{6}\right)$ of parasites induce a skewed TH1 response in resistant mice and a $\mathrm{TH} 2$ response in susceptible mice, while inocula similar to the natural infection $\left(\sim 10^{2}\right)$ induce a mixed TH1/TH2 response in both resistant and susceptible mice (Uzonna \& Bretscher 2001, Uzonna et al. 2001). There is also a strong evidence of parasite clearance by a skewed TH1 response in susceptible mice (Uzonna et al. 2001). Also important are the observations that immunity can be achieved and lost in asymptomatic mice, being maintened in a subclinical status by persistent low parasite numbers (Uzonna et al. 2001). Similar results have been obtained for resistant mice, in which a TH2 response is necessary to maintain the subclinical state (Belkaid et al. 2001). Unexpectedly, the possibility of parasite retransmission to its vector is higher with a low inoculum, similar to a natural one, inducing subclinical states. Thus the evolutionary mechanisms apparently select for the optimal condition that gives the best chances of infection and retransmission by a host, unknown a priori, if resistant or susceptible, maintaining the parasite cycle.

\section{GENERAL COMMENTS}

The main driving force leading to increasing comprehension of the initial steps in leishmaniasis is the man possession of strategies that avoid parasite infection. The strategy that best fit this goal appears to be a vaccine. In this respect, the results obtained focusing in initial steps has led to new promising results obtained using insect salivary peptides and low dose inocula in mice. The eliciting of antibodies or other strategies that retard parasite phagocytose could be also a logical step, as metacyclic serum resistance is a time dependent process. More immediate and practical results have emerged in the potential use of salivary peptides in epidemiological studies. Besides that, we could be taught by insect and parasite new strategies for avoiding inflammation and coagulation. 


\section{ACKNNOWLEDGEMENTS}

To all the personnel at the Laboratory of Immunoregulation and Laboratory of Immunoparasitology at Fiocruz/BA for fruitful discussions.

\section{REFERENCES}

Abbas AK, Lichtman AH, Pober JS 2000. Immunologic tolerance. In AK Abbas, AH Lichtman, JS Pober (eds), Cellular and Molecular Immunology, 4th ed., WB Saunders, Philadelphia, p. 208-231.

Adler S, Theodor O 1931. Investigations on Mediterranean Kala azar I-V. Proc Royal Soc, Series B, 108: 447-502.

Adler S, Theodor O 1935. Investigations on Mediterranean Kala azar VII-X. Proc Royal Soc, Series B, 116: 494-544.

Alexander J, Satoskar AR, Russell DG 1999. Leishmania species: models of intracellular parasitism. J Cell Sci $112 \mathrm{Pt}$ 18: 2993-3002.

Barral A, Honda E, Caldas A, Costa J, Vinhas V, Rowton ED, Valenzuela JG, Charlab R, Barral-Netto M, Ribeiro JM 2000. Human immune response to sand fly salivary gland antigens: a useful epidemiological marker? Am J Trop Med Hyg 62: 740-745.

Becker I, Salaiza N, Aguirre M, Delgado J, Carrillo-Carrasco N, Kobeh LG, Ruiz A, Cervantes R, Torres AP, Cabrera N, Gonzalez A, Maldonado C, Isibasi A 2003. Leishmania lipophosphoglycan (LPG) activates NK cells through tolllike receptor-2. Mol Biochem Parasitol 130: 65-74.

Belkaid Y, Hoffmann KF, Mendez S, Kamhawi S, Udey MC, Wynn TA, Sacks DL 2001. The role of interleukin (IL)-10 in the persistence of Leishmania major in the skin after healing and the therapeutic potential of anti-IL-10 receptor antibody for sterile cure. J Exp Med 194: 1497-1506.

Belkaid Y, Kamhawi S, Modi G, Valenzuela J, Noben-Trauth N, Rowton E, Ribeiro J, Sacks DL 1998. Development of a natural model of cutaneous leishmaniasis: powerful effects of vector saliva and saliva preexposure on the long-term outcome of Leishmania major infection in the mouse ear dermis. J Exp Med 188: 1941-1953.

Belkaid Y, Valenzuela JG, Kamhawi S, Rowton E, Sacks DL, Ribeiro JM 2000. Delayed-type hypersensitivity to Phlebotomus papatasi sand fly bite: an adaptive response induced by the fly? Proc Natl Acad Sci USA 97: 6704-6709.

Bernard GR, Vincent JL, Laterre PF, LaRosa SP, Dhainaut JF, Lopez-Rodriguez A, Steingrub JS, Garber GE, Helterbrand JD, Ely EW, Fisher Jr CJ 2001. Efficacy and safety of recombinant human activated protein $\mathrm{C}$ for severe sepsis. N Engl J Med 344: 699-709.

Biedermann T, Zimmermann S, Himmelrich H, Gumy A, Egeter O, Sakrauski AK, Seegmuller I, Voigt H, Launois P, Levine AD, Wagner H, Heeg K, Louis JA, Rocken M 2001. IL-4 instructs TH1 responses and resistance to Leishmania major in susceptible BALB/c mice. Nat Immunol 2: 10541060.

Blank C, Fuchs H, Rappersberger K, Rollinghoff M, Moll H 1993. Parasitism of epidermal Langerhans cells in experimental cutaneous leishmaniasis with Leishmania major. J Infect Dis 167: 418-425.

Borges MM, Campos-Neto A, Sleath P, Grabstein KH, Morrissey PJ, Skeiky YA, Reed SG 2001. Potent stimulation of the innate immune system by a Leishmania brasiliensis recombinant protein. Infect Immun 69: 5270-5277.

Brittingham A, Morrison CJ, McMaster WR, McGwire BS, Chang KP, Mosser DM 1995. Role of the Leishmania surface protease gp63 in complement fixation, cell adhesion, and resistance to complement-mediated lysis. J Immunol 155: 3102-3111.
Brodskyn CI, DeKrey GK, Titus RG 2001. Influence of costimulatory molecules on immune response to Leishmania major by human cells in vitro. Infect Immun 69: 665-672.

Brown JA, Titus RG, Nabavi N, Glimcher LH 1996. Blockade of CD86 ameliorates Leishmania major infection by downregulating the TH2 response. J Infect Dis 174: 1303-1308.

Buates S, Matlashewski G 2001. General suppression of macrophage gene expression during Leishmania donovani infection. J Immunol 166: 3416-3422.

Chang KP 1981. Leishmanicidal mechanisms of human polymorphonuclear phagocytes. Am J Trop Med Hyg 30: 322-333.

Chang KP, Chaudhuri G, Fong D 1990. Molecular determinants of Leishmania virulence. Ann Rev Microbiol 44: 499-529.

Chang KP, Nacy CA, Pearson RD 1986. Intracellular parasitism of macrophages in leishmaniasis: in vitro systems and their applications. Methods Enzymol 132: 603-626.

Chang KP, Reed SG, McGwire BS, Soong L 2003. Leishmania model for microbial virulence: the relevance of parasite multiplication and pathoantigenicity. Acta Trop 85: 375390.

Charlab R, Valenzuela JG, Rowton ED, Ribeiro JM 1999. Toward an understanding of the biochemical and pharmacological complexity of the saliva of a hematophagous sand fly Lutzomyia longipalpis. Proc Natl Acad Sci USA 96: 15155-15160.

Coffman RL, Reiner SL 1999. Instruction, selection, or tampering with the odds? Science 284: 1283-1285.

Damle NK, Klussman K, Linsley PS, Aruffo A, Ledbetter JA 1992. Differential regulatory effects of intercellular adhesion molecule-1 on costimulation by the CD28 counter-receptor B7. J Immunol 149: 2541-2548.

de Almeida MC 2002. Infective inoculum for Leishmania. Trends Parasitol 18: 154-155.

de Almeida MC, Cardoso SA, Barral-Netto M 2003. Leishmania (Leishmania) chagasi infection alters the expression of cell adhesion and costimulatory molecules on human monocyte and macrophage. Int J Parasitol 33: 153-162.

Doherty TM, Coffman RL 1996. Leishmania major: effect of infectious dose on T cell subset development in BALB/c mice. Exp Parasitol 84: 124-135.

Dominguez M, Torano A 1999. Immune adherence-mediated opsonophagocytosis: the mechanism of Leishmania infection. J Exp Med 189: 25-35.

Dominguez M, Torano A 2001. Leishmania immune adherence reaction in vertebrates. Parasite Immunol 23: 259-265.

Dominguez M, Moreno I, Lopez-Trascasa M, Torano A 2002. Complement interaction with trypanosomatid promastigotes in normal human serum. J Exp Med 195: 451-459.

el-Ghorr AA, Norval M 1997. The role of interleukin-4 in ultraviolet B light-induced immunosuppression. Immunology 92: 26-32.

Falcone FH, Haas H, Gibbs BF 2000. The human basophil: a new appreciation of its role in immune responses. Blood 96: 4028-4038.

Franke ED, McGreevy PB, Katz SP, Sacks DL 1985. Growth cycle-dependent generation of complement-resistant Leishmania promastigotes. J Immunol 134: 2713-2718.

Ghalib HW, Whittle JA, Kubin M, Hashim FA, el-Hassan AM, Grabstein KH, Trinchieri G, Reed SG 1995. IL-12 enhances TH1-type responses in human Leishmania donovani infections. J Immunol 154: 4623-4629.

Gillespie RD, Mbow ML, Titus RG 2000. The immunomodulatory factors of bloodfeeding arthropod saliva. Parasite Immunol 22: 319-331.

Gomes RB, Brodskyn C, de Oliveira CI, Costa J, Miranda JC, Caldas A, Valenzuela JG, Barral-Netto M, Barral A 2002. 
Seroconversion against Lutzomyia longipalpis saliva concurrent with the development of anti-Leishmania chagasi delayed-type hypersensitivity. J Infect Dis 186: 1530-1534.

Giannini MS 1986. Suppression of pathogenesis in cutaneous leishmaniasis by UV irradiation. Infect Immun 51: 838-843.

Gorak PM, Engwerda CR, Kaye PM 1998. Dendritic cells, but not macrophages, produce IL-12 immediately following Leishmania donovani infection. Eur J Immunol 28: 687-695.

Gosselin EJ, Wardwell K, Rigby WF, Guyre PM 1993. Induction of MHC class II on human polymorphonuclear neutrophils by granulocyte/macrophage colony-stimulating factor, IFNgamma, and IL-3. J Immunol 151: 1482-1490.

Hawn TR, Ozinsky A, Underhill DM, Buckner FS, Akira S, Aderem A 2002. Leishmania major activates IL-1 alpha expression in macrophages through a MyD88-dependent pathway. Microbes Infect 4: 763-771.

Hayashi F, Means TK, Luster AD 2003. Toll-like receptors stimulate human neutrophil function. Blood 102: 2660-2669.

Himmelrich H, Launois P, Maillard I, Biedermann T, TacchiniCottier F, Locksley RM, Rocken M, Louis JA 2000. In $\mathrm{BALB} / \mathrm{c}$ mice, IL-4 production during the initial phase of infection with Leishmania major is necessary and sufficient to instruct $\mathrm{TH} 2$ cell development resulting in progressive disease. J Immunol 164: 4819-4825.

Hunter CA, Reiner SL 2000. Cytokines and T cells in host defense. Curr Opin Immunol 12: 413-418.

Jebbari H, Stagg AJ, Davidson RN, Knight SC 2002. Leishmania major promastigotes inhibit dendritic cell motility in vitro. Infect Immun 70: 1023-1026.

Kalinski P, Hilkens CM, Snijders A, Snijdewint FG, Kapsenberg ML 1997. IL-12-deficient dendritic cells, generated in the presence of prostaglandin E2, promote type 2 cytokine production in maturing human naive T helper cells. $J$ Immunol 159: 28-35.

Kamhawi S 2000. The biological and immunomodulatory properties of sand fly saliva and its role in the establishment of Leishmania infections. Microbes Infect 2: 1765-1773.

Kaye PM 1995. Costimulation and the regulation of antimicrobial immunity. Immunol Today 16: 423-427.

Kaye PM, Rogers NJ, Curry AJ, Scott JC 1994. Deficient expression of co-stimulatory molecules on Leishmaniainfected macrophages. Eur J Immunol 24: 2850-2854.

Khaskhely NM, Maruno M, Takamiyagi A, Uezato H, Kasem KM, Hosokawa A, Kariya K, Hashiguchi Y, Landires EA, Nonaka S 2001. Pre-exposure with low-dose UVA suppresses lesion development and enhances Th1 response in BALB/c mice infected with Leishmania (Leishmania) amazonensis. J Dermatol Sci 26: 217-232.

Khaskhely NM, Maruno M, Uezato H, Takamiyagi A, Ramzi ST, Al-Kasem KM, Kariya K, Toda T, Hashiguchi Y, Gomez Landires EA, Nonaka S 2002. Low-dose UVB contributes to host resistance against Leishmania amazonensis infection in mice through induction of gamma interferon and tumor necrosis factor alpha cytokines. Clin Diagn Lab Immunol 9: 677-686.

Killick-Kendric R 1987. Biology of Leishmania in phlebotomine sandflies. In Killick-Kendric R, Peters W (eds), The Leishmaniases in Biology and Medicine, Academic Press, London, p. 392-460.

Killick-Kendrick R 1990a. The life-cycle of Leishmania in the sandfly with special reference to the form infective to the vertebrate host. Ann Parasitol Hum Comp 65: 37-42.

Killick-Kendrick R 1990b. Phlebotomine vectors of the leishmaniases: a review. Med Vet Entomol 4: 1-24.

Kim JJ, Tsai A, Nottingham LK, Morrison L, Cunning DM, Oh J, Lee DJ, Dang K, Dentchev T, Chalian AA, Agadjanyan MG, Weiner DB 1999. Intracellular adhesion molecule-1 modulates beta-chemokines and directly costimulates $\mathrm{T}$ cells in vivo. J Clin Invest 103: 869-877.

Konecny P, Stagg AJ, Jebbari H, English N, Davidson RN, Knight SC 1999. Murine dendritic cells internalize Leishmania major promastigotes, produce IL-12 p40 and stimulate primary T cell proliferation in vitro. Eur J Immunol 29: 1803-1811.

Kurts C, Sutherland RM, Davey G, Li M, Lew AM, Blanas E, Carbone FR, Miller JF, Heath WR 1999. CD8 T cell ignorance or tolerance to islet antigens depends on antigen dose. Proc Natl Acad Sci USA 96: 12703-12707.

Kweider M, Lemesre JL, Santoro F, Kusnierz JP, Sadigursky M, Capron A 1989. Development of metacyclic Leishmania promastigotes is associated with the increasing expression of GP65, the major surface antigen. Parasite Immunol 11: 197-209.

Lane PJ, Brocker T 1999. Developmental regulation of dendritic cell function. Curr Opin Immunol 11: 308-313.

Lainson R, Ryan L, Shaw JJ 1987. Infective stages of Leishmania in the sandfly vector and some observations on the mechanism of transmission. Mem Inst Oswaldo Cruz 82: 421-424.

Launois P, Himmelrich H, Tacchini-Cottier F, Milon G, Louis JA 1999. New insight into the mechanisms underlying TH2 cell development and susceptibility to Leishmania major in BALB/c mice. Microbes Infect 1: 59-64.

Launois P, Swihart KG, Milon G, Louis JA 1997. Early production of IL-4 in susceptible mice infected with Leishmania major rapidly induces IL-12 unresponsiveness. J Immunol 158: 3317-3324.

Lerner EA, Ribeiro JM, Nelson RJ, Lerner MR 1991. Isolation of maxadilan, a potent vasodilatory peptide from the salivary glands of the sand fly Lutzomyia longipalpis. J Biol Chem 266: 11234-11236.

Lira R, Doherty M, Modi G, Sacks D 2000. Evolution of lesion formation, parasitic load, immune response, and reservoir potential in C57BL/6 mice following high- and low-dose challenge with Leishmania major. Infect Immun 68: 51765182.

Lonardoni MV, Russo M, Jancar S 2000. Essential role of platelet-activating factor in control of Leishmania (Leishmania) amazonensis infection. Infect Immun 68: 6355-63561.

Luksch CR, Winqvist O, Ozaki ME, Karlsson L, Jackson MR, Peterson PA, Webb SR 1999. Intercellular adhesion molecule-1 inhibits interleukin 4 production by naive $\mathrm{T}$ cells. Proc Natl Acad Sci U S A 96: 3023-3028.

Mahoney AB, Sacks DL, Saraiva E, Modi G, Turco SJ 1999. Intra-species and stage-specific polymorphisms in lipophosphoglycan structure control Leishmania donovanisand fly interactions. Biochemistry 38: 9813-9823.

Marovich MA, McDowell MA, Thomas EK, Nutman TB 2000. IL-12p70 production by Leishmania major-harboring human dendritic cells is a CD40/CD40 ligand-dependent process. J Immunol 164: 5858-5865.

Marth T, Kelsall BL 1997. Regulation of interleukin-12 by complement receptor 3 signaling. J Exp Med 185: 19871995.

Mazzoni A, Young HA, Spitzer JH, Visintin A, Segal DM 2001. Histamine regulates cytokine production in maturing dendritic cells, resulting in altered T cell polarization. J Clin Invest 108: 1865-1873.

Medzhitov R, Janeway Jr. C 2000. Innate immunity. N Engl J Med 343: 338-344.

Mellman I, Turley SJ, Steinman RM 1998. Antigen processing for amateurs and professionals. Trends Cell Biol 8: 231237. 
McConville MJ, Turco SJ, Ferguson MA, Sacks DL 1992. Developmental modification of lipophosphoglycan during the differentiation of Leishmania major promastigotes to an infectious stage. Embo J 11: 3593-3600.

Menon JN, Bretscher PA 1998. Parasite dose determines the TH1/TH2 nature of the response to Leishmania major independently of infection route and strain of host or parasite. Eur J Immunol 28: 4020-4028.

Moore KJ, Matlashewski G 1994. Intracellular infection by Leishmania donovani inhibits macrophage apoptosis. $J$ Immunol 152: 2930-2937.

Morris RV, Shoemaker CB, David JR, Lanzaro GC, Titus RG 2001. Sandfly maxadilan exacerbates infection with Leishmania major and vaccinating against it protects against L. major infection. J Immunol 167: 5226-5230.

Mosser DM, Brittingham A 1997. Leishmania, macrophages and complement: a tale of subversion and exploitation. Parasitology 115: S9-23.

Mosser DM, Burke SK, Coutavas EE, Wedgwood JF, Edelson PJ 1986. Leishmania species: mechanisms of complement activation by five strains of promastigotes. Exp Parasitol 62: 394-404.

Mosser DM, Edelson PJ 1987. The third component of complement $(\mathrm{C} 3)$ is responsible for the intracellular survival of Leishmania major. Nature 327: 329-331.

Murphy ML, Engwerda CR, Gorak PM, Kaye PM 1997. B72 blockade enhances $\mathrm{T}$ cell responses to Leishmania donovani. J Immunol 159: 4460-4466.

Nagata K, Tsuji T, Todoroki N, Katagiri Y, Tanoue K, Yamazaki H, Hanai N, Irimura T 1993. Activated platelets induce superoxide anion release by monocytes and neutrophils through P-selectin (CD62). J Immunol 151: 3267-3273.

Nicolas L, Sidjanski S, Colle JH, Milon G 2000. Leishmania major reaches distant cutaneous sites where it persists transiently while persisting durably in the primary dermal site and its draining lymph node: a study with laboratory mice. Infect Immun 68: 6561-6566.

Nishio M, Podack ER 1996. Rapid induction of tumor necrosis factor cytotoxicity in naive splenic $\mathrm{T}$ cells by simultaneous CD80 (B7.1) and CD54 (ICAM-1) co-stimulation. Eur J Immunol 26: 2160-2164.

Peritt D, Robertson S, Gri G, Showe L, Aste-Amezaga M, Trinchieri G 1998. Differentiation of human NK cells into NK1 and NK2 subsets. J Immunol 161: 5821-5824

Pimenta PF, Saraiva EM, Sacks DL 1991. The comparative fine structure and surface glycoconjugate expression of three life stages of Leishmania major. Exp Parasitol 72: 191-204.

Pimenta PF, Turco SJ, McConville MJ, Lawyer PG, Perkins PV, Sacks DL 1992. Stage-specific adhesion of Leishmania promastigotes to the sandfly midgut. Science 256: $1812-$ 1815.

Poulter LW, Pandolph CR 1982. Mechanisms of immunity to leishmaniasis. IV. Significance of lymphatic drainage from the site of infection. Clin Exp Immunol 48: 396-402.

Puentes SM, da Silva RP, Sacks DL, Hammer CH, Joiner KA 1990. Serum resistance of metacyclic stage Leishmania major promastigotes is due to release of C5b-9. J Immunol 145: 4311-4316.

Puentes SM, Sacks DL, da Silva RP, Joiner KA 1988. Complement binding by two developmental stages of Leishmania major promastigotes varying in expression of a surface lipophosphoglycan. J Exp Med 167: 887-902.

Ramamoorthy R, Donelson JE, Paetz KE, Maybodi M, Roberts SC, Wilson ME 1992. Three distinct RNAs for the surface protease gp63 are differentially expressed during development of Leishmania donovani chagasi promastigotes to an infectious form. J Biol Chem 267: 1888-1895.
Reiner NE 1994. Altered cell signaling and mononuclear phagocyte deactivation during intracellular infection. Immunol Today 15: 374-381.

Reiner NE, Ng W, McMaster WR 1987. Parasite-accessory cell interactions in murine leishmaniasis. II. Leishmania donovani suppresses macrophage expression of class I and class II major histocompatibility complex gene products. JImmunol 138: 1926-1932.

Reiner NE, Ng W, Wilson CB, McMaster WR, Burchett SK 1990. Modulation of in vitro monocyte cytokine responses to Leishmania donovani. Interferon-gamma prevents parasite-induced inhibition of interleukin 1 production and primes monocytes to respond to Leishmania by producing both tumor necrosis factor-alpha and interleukin 1. J Clin Invest 85: 1914-1924.

Reiner SL, Locksley RM 1995. The regulation of immunity to Leishmania major. Ann Rev Immunol 13: 151-177.

Reiner SL, Zheng S, Wang ZE, Stowring L, Locksley RM 1994. Leishmania promastigotes evade interleukin 12 (IL-12) induction by macrophages and stimulate a broad range of cytokines from $\mathrm{CD} 4+\mathrm{T}$ cells during initiation of infection. J Exp Med 179: 447-456.

Ribeiro JM 1987. Role of saliva in blood-feeding by arthropods. Ann Rev Entomol 32: 463-478.

Ribeiro JM, Katz O, Pannell LK, Waitumbi J, Warburg A 1999. Salivary glands of the sand fly Phlebotomus papatasi contain pharmacologically active amounts of adenosine and 5'-AMP. J Exp Biol 202: 1551-1559.

Ribeiro JM, Rossignol PA, Spielman A 1984. Role of mosquito saliva in blood vessel location. J Exp Biol 108: 1-7.

Rosenthal LA, Sutterwala FS, Kehrli ME, Mosser DM 1996. Leishmania major-human macrophage interactions: cooperation between Mac-1 (CD11b/CD18) and complement receptor type 1 (CD35) in promastigote adhesion. Infect Immun 64: 2206-2215.

Sacks DL 1989. Metacyclogenesis in Leishmania promastigotes. Exp Parasitol 69: 100-103.

Sacks DL, Perkins PV 1985. Development of infective stage Leishmania promastigotes within phlebotomine sand flies. Am J Trop Med Hyg 34: 456-459.

Saha B, Das G, Vohra H, Ganguly NK, Mishra GC 1995. Macrophage-T cell interaction in experimental visceral leishmaniasis: failure to express costimulatory molecules on Leishmania-infected macrophages and its implication in the suppression of cell-mediated immunity. Eur J Immunol 25: 2492-2498.

Sartori A, Oliveira MA, Scott P, Trinchieri G 1997. Metacyclogenesis modulates the ability of Leishmania promastigotes to induce IL-12 production in human mononuclear cells. J Immunol 159: 2849-2857.

Sato N, Ahuja SK, Quinones M, Kostecki V, Reddick RL, Melby PC, Kuziel WA, Ahuja SS 2000. CC chemokine receptor (CCR)2 is required for langerhans cell migration and localization of Thelper cell type 1 (Th1)-inducing dendritic cells. Absence of CCR2 shifts the Leishmania majorresistant phenotype to a susceptible state dominated by Th2 cytokines, B cell outgrowth, and sustained neutrophilic inflammation. J Exp Med 192: 205-218.

Scharton-Kersten T, Scott P 1995. The role of the innate immune response in TH1 cell development following Leishmania major infection. J Leukoc Biol 57: 515-522.

Schlein Y, Borut S, Greenblatt CL 1987. Development of sandfly forms of Leishmania major in sucrose solutions. J Parasitol 73: 797-805.

Schmitt DA, Ullrich SE 2000. Exposure to ultraviolet radiation causes dendritic cells/macrophages to secrete immune- 
suppressive IL-12p40 homodimers. J Immunol 165: 31623167.

Scott P 1991. IFN-gamma modulates the early development of TH1 and TH2 responses in a murine model of cutaneous leishmaniasis. J Immunol 147: 3149-3155.

Sharpe AH, Freeman GJ 2002. The B7-CD28 superfamily. Nat Rev Immunol 2: 116-26.

Shaw JJ, Lainson R 1987. Ecology and epidemiology: New World. In Killick-Kendric R, Peters W(eds), The Leishmaniases in Biology and Medicine, Academic Press, London, p. 1-120.

Shevach EM 1999. Organ-specific autoimmunity. Chapter 34. In WE Paul, Fundamental Immunology, 4th ed., Lippincott, Raven, New York.

Shi HZ, Humbles A, Gerard C, Jin Z, Weller PF 2000. Lymph node trafficking and antigen presentation by endobronchial eosinophils. J Clin Invest 105: 945-953.

Shreedhar V, Giese T, Sung VW, Ullrich SE 1998. A cytokine cascade including prostaglandin E2, IL-4, and IL-10 is responsible for UV-induced systemic immune suppression. J Immunol 160: 3783-3789.

Skeiky YA, Kennedy M, Kaufman D, Borges MM, Guderian JA, Scholler JK, Ovendale PJ, Picha KS, Morrissey PJ, Grabstein KH, Campos-Neto A, Reed SG 1998. LeIF: a recombinant Leishmania protein that induces an IL-12mediated Th1 cytokine profile. J Immunol 161: 6171-6179.

Soares MB, Titus RG, Shoemaker CB, David JR, Bozza M 1998. The vasoactive peptide maxadilan from sand fly saliva inhibits TNF-alpha and induces IL- 6 by mouse macrophages through interaction with the pituitary adenylate cyclaseactivating polypeptide (PACAP) receptor. J Immunol 160: 1811-1816.

Stenger S, Donhauser N, Thuring H, Rollinghoff M, Bogdan C 1996. Reactivation of latent leishmaniasis by inhibition of inducible nitric oxide synthase. J Exp Med 183: 1501-1514.

Sutterwala FS, Noel GJ, Clynes R, Mosser DM 1997. Selective suppression of interleukin-12 induction after macrophage receptor ligation. J Exp Med 185: 1977-1985.

Tacchini-Cottier F, Zweifel C, Belkaid Y, Mukankundiye C, Vasei M, Launois P, Milon G, Louis JA 2000. An immunomodulatory function for neutrophils during the induction of a CD4+ TH2 response in BALB/c mice infected with Leishmania major. J Immunol 165: 2628-2636.

Tsuyuki S, Tsuyuki J, Einsle K, Kopf M, Coyle AJ 1997. Costimulation through B7-2 (CD86) is required for the induction of a lung mucosal $\mathrm{T}$ helper cell 2 (TH2) immune response and altered airway responsiveness. $J$ Exp Med 185: 1671-1679.

Urmacher CD 1997. Normal skin. In SS Stenberg, Histology for Pathologists, Lippicott-Raven, Philadelphia, p. 25-45.
Uzonna JE, Bretscher PA 2001. Anti-IL-4 antibody therapy causes regression of chronic lesions caused by mediumdose Leishmania major infection in BALB/c mice. Eur $J$ Immunol 31: 3175-3184.

Uzonna JE, Wei G, Yurkowski D, Bretscher P 2001. Immune elimination of Leishmania major in mice: implications for immune memory, vaccination, and reactivation disease. $J$ Immunol 167: 6967-6974.

Valenzuela JG, Belkaid Y, Garfield MK, Mendez S, Kamhawi S, Rowton ED, Sacks DL, Ribeiro JM 2001. Toward a defined anti-Leishmania vaccine targeting vector antigens: characterization of a protective salivary protein. $J$ Exp Med 194: 331-342.

Valenzuela JG, Belkaid Y, Rowton E, Ribeiro JM 2001. The salivary apyrase of the blood-sucking sand fly Phlebotomus papatasi belongs to the novel Cimex family of apyrases. $J$ Exp Biol 204: 229-237.

Voehringer D, Blaser C, Grawitz AB, Chisari FV, Buerki K, Pircher H 2000. Break of T Cell ignorance to a viral antigen in the liver induces hepatitis. J Immunol 165: 2415-2422.

von Stebut E, Belkaid Y, Jakob T, Sacks DL, Udey MC 1998. Uptake of Leishmania major amastigotes results in activation and interleukin 12 release from murine skinderived dendritic cells: implications for the initiation of antiLeishmania immunity. J Exp Med 188: 1547-1552.

von Stebut E, Belkaid Y, Nguyen BV, Cushing M, Sacks DL, Udey MC 2000. Leishmania major-infected murine langerhans cell-like dendritic cells from susceptible mice release IL-12 after infection and vaccinate against experimental cutaneous Leishmaniasis. Eur J Immunol 30: 3498-3506.

Walters LL, Chaplin GL, Modi GB, Tesh RB 1989a. Ultrastructural biology of Leishmania (Viannia) panamensis (= Leishmania braziliensis panamensis) in Lutzomyia gomezi (Diptera: Psychodidae): a natural host-parasite association. Am J Trop Med Hyg 40: 19-39.

Walters LL, Modi GB, Chaplin GL, Tesh RB 1989b. Ultrastructural development of Leishmania chagasi in its vector, Lutzomyia longipalpis (Diptera: Psychodidae). Am J Trop Med Hyg 41: 295-317.

Warburg A, Schlein Y 1986. The effect of post-bloodmeal nutrition of Phlebotomus papatasi on the transmission of Leishmania major. Am J Trop Med Hyg 35: 926-930.

Weller PF, Lim K 1997. Human eosinophil-Lymphocyte interactions. Mem Inst Oswaldo Cruz 92 (Suppl. II): 173182.

Weyrich AS, Elstad MR, McEver RP, McIntyre TM, Moore KL, Morrissey JH, Prescott SM, Zimmerman GA 1996. Activated platelets signal chemokine synthesis by human monocytes. J Clin Invest 97: 1525-1534. 